\begin{tabular}{|c|c|c|c|}
\hline Article Info & RESEARCH ARTICLE & ARAŞTIRMA MAKALESİ & \\
\hline Title of Article & \multicolumn{2}{|c|}{$\begin{array}{c}\text { Ecological Design Suggestions in } \\
\text { Çanakkale Sarıçay Creek and its Environs }\end{array}$} & \\
\hline $\begin{array}{l}\text { Corresponding } \\
\text { Author }\end{array}$ & \multicolumn{2}{|c|}{$\begin{array}{l}\text { Alper SAĞLIK } \\
\text { Çanakkale Onsekiz Mart Üniversitesi, Mimarlık ve Tasarım Fakültesi, Peyzaj Mimarlı̆̆ı } \\
\text { Bölümü, alpersaglik@gmail.com }\end{array}$} & \\
\hline $\begin{array}{l}\text { Received Date } \\
\text { Accepted Date }\end{array}$ & \multicolumn{2}{|c|}{$\begin{array}{l}14.05 .2021 \\
05.07 .2021\end{array}$} & \\
\hline DOI Number & \multicolumn{2}{|l|}{ https://doi.org/10.35674/kent.937164 } & \\
\hline Author / Authors & $\begin{array}{l}\text { Alper SAĞLIK } \\
\text { Fatoş KARTAL } \\
\text { Dilan ŞENKUŞ } \\
\text { Merve TEMIZ }\end{array}$ & $\begin{array}{l}\text { ORCID: } 0000-0003-1156-1201 \\
\text { ORCID: } 0000-0003-3897-7493 \\
\text { ORCID: } 0000-0002-4577-7580 \\
\text { ORCID: } 0000-0002-6662-4399\end{array}$ & \\
\hline How to Cite & \multicolumn{2}{|c|}{$\begin{array}{l}\text { SAĞLIK, A., KARTAL, F., ŞENKUŞ, D. and TEMİ, M. (2021). } \\
\text { Çanakkale Sarıçay ve Yakın Çevresinde Ekolojik Tasarım Önerileri, Kent } \\
\text { Akademisi, Volume, } 13 \text { (43), Issue 3, Pages, 578-592 }\end{array}$} & $\begin{array}{l}\text { Kent Akademisi } \\
\text { Uriban Academy }\end{array}$ \\
\hline
\end{tabular}

\title{
Çanakkale Sarıçay ve Yakın Çevresinde Ekolojik Tasarım Önerileri
}

\section{ABSTRACT:}

Ecological landscape design is taken as a model as production, its close design is a hardware. Designing a sustainable living space is the main goal of ecological design. Therefore, ecological design should be applied in order to ensure that the design created by human influence can become a whole with the natural area. This study covers the Sarıçay River and its immediate surroundings, which is an important ecological resource for Çanakkale city. With this study, it is aimed to reveal the ecological potential of Sarıçay River and its vicinity, which is an important natural resource for Çanakkale city, and to make it valuable. In this context, Sarıçay River and its immediate surroundings; In terms of ecological principles, it has been examined under the titles of wetlands, hard grounds, vegetative elements, waste bins and land uses. When the study area was examined in line with the ecological landscape design criteria, it was found that it did not meet these criteria. In the area, problems such as the wetlands are neglected and dirty, the hard floors create heat islands by dominating the area, the vegetative designs are quite insufficient and disconnected, the building materials used in the garbage bins are not integrated into the area, and the area uses are concentrated in a single point. The

\footnotetext{
${ }^{1}$ Çanakkale Onsekiz Mart University, Faculty of Architecture\&Design, Department of Landscape Architecture, alpersaglik@gmail.com

${ }^{2}$ Çanakkale Onsekiz Mart University, Faculty of Architecture\&Design, Department of Landscape Architecture, f.kartal2@hotmail.com

${ }^{3}$ Çanakkale Onsekiz Mart University, Faculty of Architecture\&Design, Department of Landscape Architecture, dilansenkus@hotmail.com

${ }^{4}$ Çanakkale Onsekiz Mart University, Faculty of Architecture\&Design, Department of Landscape Architecture, mervetemiz@.comu.edu.tr
} 
ecological potential of the Seine River, which is similar to the study area, was compared and solutions were proposed for the problems.

KEYWORDS: Ecological landscape design, Sarıçay, Coastal areas, Sustainability.

ÖZ:

Ekolojik peyzaj tasarımı, doğanın model olarak alındığı, doğala yakın tasarımı hedefleyen bir yaklaşımdır. Sürdürülebilir bir yaşam alanı oluşturmak ekolojik peyzaj tasarımının temel amacıdır. Dolayısıyla insan etkisiyle ortaya çıkarılan tasarımın, doğal alanla bir bütün haline gelebilmesini sağlamak amacıyla ekolojik tasarım uygulanmalıdır. Bu çalışma, Çanakkale kenti açısından önemli bir ekolojik kaynak olan Sarıçay Nehri ve yakın çevresini kapsamaktadır. $\mathrm{Bu}$ çalışma ile Çanakkale kenti için önemi bir doğal kaynak olan Sarıçay Nehri ve yakın çevresinin ekolojik açıdan potansiyelinin ortaya koyulması ve değerli bir duruma getirilmesi amaçlanmaktadır. Bu bağlamda Sarıçay Nehri ve yakın çevresi; ekolojik ilkeler açısından sulak alanlar, sert zeminler, bitkisel öğeler, çöp kutuları ve alan kullanımları başlıkları altında incelenmiştir. Çalışma alanı, ekolojik peyzaj tasarımı kriterleri doğrultusunda incelendiğinde bu kriterleri karşılamadığı tespit edilmiştir. Alanda, sulak alanların bakımsız ve kirli olduğu, sert zeminlerin alana oldukça hâkim olarak 1S1 adaları yarattı̆̆ı, bitkisel tasarımların oldukça yetersiz ve kopuk olduğu, çöp kutularında kullanılan yapı malzemelerinin alana entegre edilmemiş olduğu, alan kullanımlarının tek bir noktada toplanmış olması gibi sorunlar saptanmıştır. Çalışma alanı ile benzerlik gösteren Seine Nehri ekolojik potansiyel olarak karşılaştırılmış ve sorunlara yönelik çözüm önerileri getirilmiştir.

ANAHTAR KELIMELER: Ekolojik peyzaj tasarımı, Kıyı alanları, Sarıçay, Sürdürülebilirlik.

\section{GíRIŞ:}

Kıyı alanları, suyun tasarımla bir araya geldiği, görsel etkileşim içerisinde olduğu, oldukça önemli bölgelerdir. Su ve kara parçası arasındaki hat olarak bilinen kıyı; her çeşit su yığınını kuşatan toprak hattıdır. Bu kelime anlamı doğrultusunda kıyı alanları bir toprak şerididir. Bu kara parçasına kıyı özelliği veren temel unsur; su kitlesi ile yan yana bulunmasıdır (Sağlık, 2010).

Kıyı alanları kentlerde bulunan özel toprak parçalarıdır. Mekânsal tasarım imkânları yönünden eşsiz özellikler barındırırlar. Bulundukları konumun yanı sıra meydana getirdikleri; kültürel, sosyal ve ekonomik potansiyelleri de diğer toprak parçalarından farklılaşmasını sağlamaktadır. Bu sebeptendir ki kıyılar; eski çağlarda medeniyetlerin yerleşme bölgesi olarak ilk sirada tercih ettikleri alanlardır (Moore ve Lidz, 1994).

Teknolojinin gelişimi ile endüstriyel kullanımlar, ulaşım ve depolama gibi sebeplerden ötürü kıyı alanlarında yer almışlardır. Ancak sanayileşme ve kentleşmenin hızla yükselişi, kıyıların dinleme amaçlı meydana gelen kullanımına da sebep olmuştur (Sağlık ve ark., 2012). Kentleşmenin artmasıyla beraber çevre kirliliği, kent içi düzensizlik ve doğal hayattan uzaklaşma da aynı oranda artış göstermiştir. Bu olumsuz etkenler yerleşimlerin kıyı boyunca bir şerit şeklinde ilerlemesi, doğal bağlantılarda noksanlığa, siluet değerlerinin azalmasına, kamu hizmetlerinden yeterli olarak yararlanılamamasına neden olmaktadır. Ayrıca denizlere bırakılan evsel ve endüstriyel atıklar ise su kalitesine oldukça zarar vermektedir (Sağlik ve ark., 2012).

Dereler, nehirler, göletler, göller, drenaj hatlarının su toplama rezervuarları gibi türlü boyut ve şekillerde olabilen su kütleleri, peyzaj alanında hem rekreasyonel hem de işlevsel olarak önemli fonksiyonlara sahiptir. Suyun kullanıldığı tasarım ve planlamalar bu yönü ile endüstriyel atıkların dökülmesi, ulaşım, balıkçılık, tarım maksatlı kullanım, temiz suyun elde edilmesi, enerji sağlama ve rekreasyonel etkinlikler gibi toplumun farklı ihtiyaçlarını ve ekolojik ilkeleri entegre edebilecek kalitede olmalıdır (Tülek, 2010).

Ekolojik yaklaşım çerçevesinde kent, bir bölgede hayatlarını devam ettiren ve birbirleriyle devamlı iletişim halinde bulunan canlıların, içerisinde bulundukları cansız çevre ile meydana getirdikleri kültürel ekosistemlerdir. Bu sebeple kentler etraflarında yer alan göl, kıyı ve orman ekosistemlerine uyum sağlayabilmeli ve onlara zarar vermemelidir (Atıl ve ark., 2005). 
Ekolojik tasarım, işlevsel tasarım sınırlarını belirleyen, insan eli değmiş çevreyi, şehirleri, binaları, peyzajı; ekosistemin bir ürünü olarak gören modern ötesinin bir örneğidir. Ekolojik tasarım toplumsal ve ruhsal etmenleri bünyesinde bulunduran, kültürel tercihleri esas alan, yöreselliği aynı zamanda sembolikliği öne getiren, doğal verilerin işleyişlerini algılayıp onlarla ahenk içinde ilerleyen bir süreçtir (Girginer, 2006).

Ken Yeang (2008)'a göre dünyada yer alan tüm ekosistemlerin içerisindeki öğeler birleşerek bir zincir meydana getirmektedir. Bu zincir bağlamında gerçekleştiren tüm değişiklikler, yerel ve kültürel anlamda ekosistemi etkilemektedir. Ekolojik tasarım, bu etkinin farkına vararak gerçekleştirilen tasarımı daha ileriye taşıyan peyzaj yöntemidir. İnsan etkisiyle ortaya çıkarılan tasarımın, doğal alanla bir bütün haline gelebilmesini sağlamak amacıyla ekolojik tasarım uygulanmalıdır (Aklanoğlu, 2009).

Ekolojik peyzaj tasarımı, doğaya duyarlı ve hassas bir anlayışı destekleyen bütünsel bir peyzaj tasarım yöntemidir. Ekolojik peyzaj tasarımına rehberlik eden üç temel amaç; peyzaj bütününün muhafaza edilmesi, sürdürülebilirliğin sağlanması ve bölgenin doğal ve kültürel özelliklerinin kuvvetlendirilmesidir (Deng ve ark., 2008).

Teknolojinin hızla gelişmesi ve kullanımının artması, insanların ekosistemler üzerinde baskısını da aynı oranda artırmıştır (Aklanoğlu, 2009). Özellikle kentleşmenin artmasıyla birlikte oluşan bu baskıların sonucunda doğal alanlarda meydana gelen tahribatlar, habitatlar üzerinde bölünmeye yol açmış ve ekosistemin devamlılığını tehlikeye atmıştır. Dolayısıyla sürdürülebilirliğin sağlanması ve doğal yaşamın korunması adına, ekolojik tasarım yaklaşımının kentler üzerinde uygulanması giderek önemini artırmaktadır.

Günümüzde yeni oluşan ve varlığını devam ettiren kentlerde, kentin doğa ile uyumu ekolojik yaklaşımla sağlanmaya başlamıştır. Doğayı ve doğal kaynakları muhafaza etmek ve devamlılı̆̆ını sağlamak endişesiyle oluşan bu yaklaşım, şehirlerin yaşam kalitesinin artırılması gerektiğini gündeme getirmiştir. Dolayısıyla son yıllarda, amacı hayat konforu sağlamak, kullanıcı ihtiyaçlarına önem vermek, mekân kalitesini artırmak ve kimlik oluşumuna katı sağlamak olan yeni bir planlama ve tasarımda anlayışı hakim olmuştur. Sorunları ekolojik yaklaşımla çözümlenmiş olan şehirlerde, kent kullanıcılarının daha iyi şartlarda, fazla tüketimden kaçınarak yaşamına devam etmesi, toplu taşımaya yönelerek özel araç kullanımının en aza indirilmesi, ayrıca daha fazla kamusal alan ve açık-yeşil alanın oluşturulması ve benzeri yaklaşımlar uygulamaya konulmuştur (Aklanoğlu ve Erdoğan, 2011).

Emery, (1986) ve Eugenio, (2003)'a göre ise peyzaj tasarlama ve yönetmede ekolojik tasarım; alanın tasarımı yapılırken içinde bulunduğu bölgenin doğal yapısını koruyarak ve doğayı taklit ederek, kendi ekolojik ve yapısal özellikleriyle uyum sağlayacak öneriler getirilmelidir. Buradaki temel amaç, şehir ekosistemine uyum sağlayan ve kendi kendini devam ettirebilen, sürdürülebilir bir düzen oluşturulmasıdır (Onur, 2012). Sürdürülebilir bir düzen geliştirilmesindeki hedef doğanın devamlılı̆̆ının sağlanarak minimum zarar ile gelecek kuşaklara aktarılması ve biyolojik çeşitliliğin korunumuna katkı sağlamaktır.

Peyzaj tasarlama ve yönetmede, ekolojik tasarım doğrultusunda verilen yedi farklı temel kriter; alana olan uyumluluk, estetik, sürdürülebilirlik, bitkisel kompozisyon, fauna yaşamı, yönetim ve onarım, alan misyonu şeklindedir. Belirtilen temel kriterin, altında da dikkat edilmesi gereken hususlar verilmiştir. Bu hususlar aşağıda özetlenmiş̧tir (Onur, 2012; Korkut ve ark., 2017).

- Alanı farklı kılan peyzaj elemanlarının muhafaza edilmesi, doğaya yapılan müdahaleler için limit olması, doğal görüntünün muhafaza edilmesi,

- Alanda yer alan habitatların korunumu ve iyileştirilmesi,

- Ekolojik koşullar (su, iklim, ışık, iklim farklılıkları vb.) ve alanın barındırdığı hem tarihi hem de kültürel özelliklerine uyumlu tasarım,

- Ekolojik önemi bulunan peyzaj estetiğine dikkat çekilmesi,

- Kullanıcıları kentten uzaklaştırarak, doğa ile iç içe olmasına yardımcı olacak aynı zamanda alanın doğayla uyumunu sağlayarak, kullanıcıların sosyal ihtiyaçlarına cevap verebilecek etkinlikler oluşturulması, 
- Bulunduğu bölgeye has olan ve geri kazanımlı, maliyeti az olan malzemeler ile yine bulunduğu bölgeye has bitki türlerinin kullanımı,

- Tükenmeyen enerji kaynaklarının tercih edilmesi,

- Enerji kullanımını en aza indirecek düzenlemeler yapılması,

- Biyolojik çeşitliliğin devamı için ortam sağlamak ve türü tehlikede olan canlılar için yaşam alanı oluşturulması,

- Bölge yönetimi ve onarımında geri kazanım sağlayacak uygulamaların tercih edilmesi,

- Sürdürülebilir, ekolojik yönetim yönteminin uygulanması,

- Şehir ekosistemlerinin ve fauna yaşamının muhafazasının sağlanması,

- Ekolojik estetik sağlanarak, kent kullanıcılarında çevre bilincinin oluşturulmasıdır (Onur, 2012; Korkut ve ark., 2017).

Kent içerisindeki fiziksel kalitenin (hava, su, iklim, vb.) artırılması ekolojik tasarımın temel amaçlarındandır. Ayrıca alanın doğal özelliklerinin korunması ve tasarım yapılırken alan kullanımlarına yeterli miktarda yer verilmesi ile doğa tahribatının minimum düzeyde tutulması, kullanıcılar için değişik aktif ve pasif rekreasyonel aktivite imkânı sağlarken, kent ortamından uzaklaşma ve doğaya yakınlaşma firsatı tanımaktadır. Bu sayede hem bedensel hem de ruhsal açıdan sağlıklı kitlelerin oluşumuna katkı sağlarken, doğal alanların muhafaza edilmesiyle beraber şimdiye kadar oluşmuş estetik anlayışın farklılaşmasına ortam sağlayacağı düşünülmektedir (Onur, 2012).

İçerisinde yer aldığı durumlarda daima gelecek kuşakları düşünerek yenilenebilir enerji kaynaklarını tercih eden, kullanıcı konforunu dikkate alan tasarımlar oluşturan, kaynakları ve içinde olduğu bölgeyi etkin kullanan faaliyetlerin hepsi sürdürülebilir mimarlığı ortaya koyar. Sürdürülebilir mimarlık, kullanıcıların mekân ihtiyaçlarını, doğaya zarar vermeden ve sürdürülebilirliğini sağlayarak karşılamayı amaçlayan tasarım ve uygulamalardır (Sev,2009; Gökşen ve ark., 2017).

Bu çalışmada, Çanakkale kentinde bulunan Sarıçay Nehri ve yakın çevresi, ekolojik ilkeler açısından sulak alanlar, sert zeminler, bitkisel öğeler, çöp kutuları ve alan kullanımları başlıkları altında incelenmiştir. Çanakkale kenti için önemli olan, ekolojik olarak kent için olumlu sonuçlar meydana getirebilecek ve ekolojik tasarım için potansiyel barındıran bu alanın, ekolojik peyzaj tasarımı kapsamında geliştirilmesine yönelik tasarım önerilerinin getirilmesi hedeflenmiştir.

\section{Materyal ve Yöntem}

\subsection{Materyal}

Çalışmanın ana materyalini Çanakkale kent merkezine $1 \mathrm{~km}$ uzaklıkta bulunan Sarıçay Nehri yakın çevresi oluşturmaktadır. Sarıçay 40.1440 enlem ve 26.3992 boylamda yer almaktadır (URL-1). Çalışma alanı olarak Sarıçay Nehri'nin Troya Köprüsü ile Atatürk Köprüsü arasında kalan yaklaşık 1,07 km'lik kısmı belirlenmiştir (Şekil 1). 


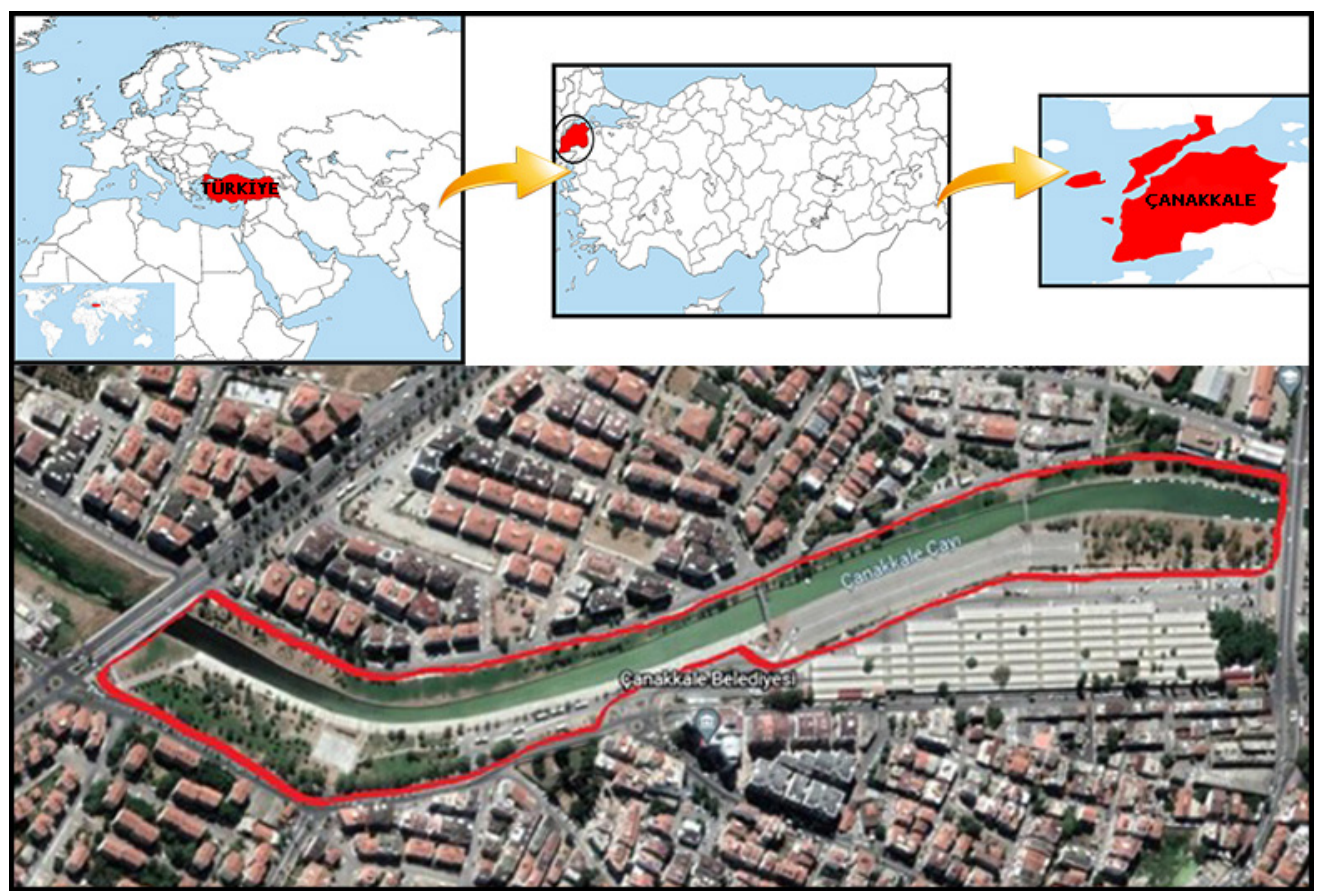

Şekil 1. Çalışma Alanı (Google Earth 2021'den değiştirilerek)

Su ve yeşil alanların bir arada bulunduğu Sarıçay Nehri ve yakın çevresi çalışma alanı olarak seçilmiştir. Bu çalışma alanının seçilmesinin amacı, doğru bir ekolojik tasarımla kent kimliği olgusunun oluşmasına katkı sağlamak ve kentin marka değerini yükseltmektir. Ayrıca, alanın kullanıcılar tarafından daha yoğun kullanılması sağlanarak, cazibe merkezi haline getirileceği ve tasarlanacak olan alternatif yeşil alanlarla yeşil kuşaklar oluşturarak sürdürülebilirliğin sağlanacağı düşünülmektedir.

Çalışma alanı içerisinde su etrafına konumlandırılmış bir adet çocuk parkı, spor aletleri alanı, iki adet basketbol sahası, çeşitli donatı elemanları, otopark, pazar yeri ve yer yer küçük peyzaj kombinasyonları da bulunmaktadır.

\subsection{Yöntem}

Araştırmada, etüt, veri toplama, analiz ve senteze dayalı peyzaj araştırma yöntemi kullanılacaktır (Sağlık ve ark., 2014). Çalı̧̧ma 4 aşamada gerçekleştirilecektir;

1-Literatür Tarama: Ekolojik tasarım yaklaşım, ilke ve uygulamaları ile sürdürülebilirlik hakkında detaylı veri taraması gerçekleştirilmiştir.

2-Alan Analizi: Çalışma alanı olan Sarıçay Nehri ve yakın çevresinde gözlemler ve fotoğraf çekimleri yapılacaktır. Mevcut kullanımlar ve peyzaj tasarımları tespit edilmiştir.

3-Değerlendirme ve Öneriler: Yapılan analiz ve gözlemler sonucu Sarıçay Nehri ve yakın çevresinde tespit edilen peyzaj kompozisyonları, alan kullanımları ve kullanılan donatı elemanları (sulak alan, yer-zemin döşemeleri, bitki öğesi, çöp kovaları) ekolojik tasarım kriterlerine göre değerlendirilmiştir. Elde edilen veriler sonucunda Sarıçay ve yakın çevresinin, Fransa'da bulunan Seine Nehri ile karşılaştırılarak, ekolojik peyzaj tasarım yaklaşımına göre uygunluğu ortaya konulmuştur.

4-Sonuç: Sarıçay Nehri ve yakın çevresinin iyileşmesi, doğayla uyumlu yeni yaşam çevrelerinin oluşması, ekolojik tasarım ilke ve uygulamaları doğrultusunda kent içinde daha faydalanılabilir ve yararlı bir mekân haline gelebilmesi adına tasarım önerilerinde bulunulmuştur.

\section{Araştırma Bulguları}




\section{1. Çalışma Alanı Hakkında Genel Bilgiler}

Osmanlı devrinde Çimenlik Kalesinin etrafında ve Sarıçay Nehrinin kuzeyinde kentsel gelişim hareketi başlatılmıştır. Zamanla artan insan sayısıyla birlikte kent gelişimini engelleyen elemanlar, gelişim planını etkileyerek olumsuz tesirler oluşturmuştur. Bunun neticesinde, 1978'de alanda başlayan planlama çalışması kentin iç bölgelerine doğru devam etmiştir. Sarıçay bölgenin beşinci büyük akarsuyu olmakla birlikte ve kaynağının da Kazdağları olduğu bilinmektedir (Sağlık ve ark., 2012).

Farklı literatürlerde Koca Çay olarak da geçen Sarıçay Nehri, Çanakkale'nin güneyinden Çimenlik Kalesi/Çanakkale'nin güneyinden Çanakkale Boğazı'na dökülür. Sarıçay Nehri yaklaşık olarak 40 km uzunluğundadır. Özellikle günümüzde nüfus artışıla doğru orantılı olarak artan sanayileşme nedeniyle, Sarıçay Nehri ve yakın çevresi devamlı olarak kirliliğe maruz kalmaktadır. Çanakkale Çan Yolu üzerinde bulunan birtakım madencilik kuruluşlarının atıkları Sarıçay'a ulaşmaktadır. Ayrıca sanayi atıkları ile Sarıçay Nehri’ne doğrudan veya gizli olarak yönlendirilen evsel atıkların olumsuz sonuçları, canlıların yaşam ortamlarına doğrudan tesir etmektedir (Tunçer, 2021).

Bu bölgede nehrin iki tarafında da konut kullanımları oldukça artmıştır. Özellikle Fevzipaşa Mahallesi çarpık kentleşme düzeni ile bölgede ciddi bir görüntü ve çevre kirliliğinin oluşmasına neden olmuştur. Bu çevre konutların evsel atıkları Sarıçay Nehrine dökülmekte, buradan da denize karışmaktadır (Sağlık ve ark., 2012).

\section{2. Çalışma Alanının Analizi}

Çanakkale kent merkezinde seyri devam eden ve kenti neredeyse ikiye bölen Sarıçay Nehri; kentin dinlenme, rekreasyon, eğlence gibi aktivitelerle desteklenerek değerlendirilmesi gereken en önemli alanlarından biridir. Özellikle su öğesini de bünyesinde bulundurması şehrin doğal hayata dönük yüzünü bizlere sunmaktadır. Fakat böylesine değerli olan Sarıçay Nehri ve yakın çevresi etkili bir şekilde kullanılmamakta, yeterli alan kullanımları ve peyzaj kompozisyonları yer almamaktadır.

\subsubsection{Sulak Alanlar}

Sulak alanlar peyzaj tasarımında kullanılan en dikkat çekici öğelerden biridir. Aynı zamanda rekreasyon alanlarında en sık tercih edilen kullanımlardandır. Su; doğa bilimlerini ilgilendirdiği kadar sosyal bilimlerinde kapsadığı bir alandır. Geçmişten günümüze, suyun ekolojik işlevlerinin toplumlarla etkileşim halinde olması kültürel süreçleri de etkilemiştir. Sulak alanlar, kullanıldıkların alanlarda mekânın peyzaj değerini oldukça yükseltmekte, kullanıcılar için her zaman dikkat çekici nitelik taşımaktadırlar (Aşur, 2017). Sarıçay Nehri ve yakın çevresi içerisinde yer yer sazlık ve yabani otlara rastlanılmaktadır. İnsan kaynaklı olan ve nehirde biriken poşet, pet şişe, kâğıt, ambalaj vb. katı atıklar suyun yüzeyin görüntü kirliliğine neden olmaktadır. Evsel ve endüstriyel atıkların nehre akıtılması sonucu; su doğal rengini yitirmiş, koyu ve bulanık bir renk almıştır. Aynı zamanda nehrin içerisinde bulunan çeşitli balık türleri, mevcut kirlilikten etkilenerek yaşamına devam edememektedir. Bu hayvan kalıntıları alanda görüntü kirliliği ile birlikte ağır bir koku kirliliğine de neden olmaktadır (Şekil 2).
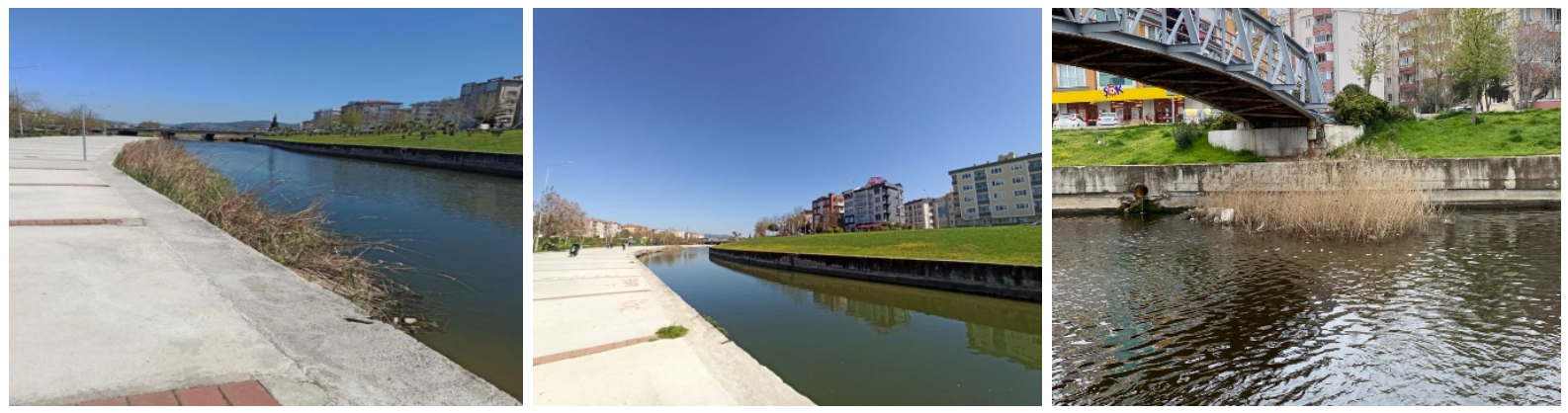

Şekil 2. Sarıçay Nehri Görüntüsü (Orijinal, 2021).

\subsubsection{Sert Zeminler}


Sarıçay Nehri ve yakın çevresini saran sert zeminler alanda ağırlıklı olarak bulunmaktadır. Zeminlerde beton, blok taş, asfalt gibi sert zemin döşemeleri kullanılmıştır. Genellikle açık renk döşeme malzemelerinin kullanılması, alanın olduğundan daha geniş ve ferah görünmesini sağlamıştır. Yoğun olarak bulunan sert zeminler kentsel 1sı adası etkisine neden olarak alanın fazla ısınmasına yol açmaktadır (Şekil 3). Zeminde beton ya da asfalt kullanılmasındansa yer örtücü çimin kullanılması sıcaklığın yaklaşık $60 \mathrm{C}$ düşürülebilmesini sağlamaktadır. Bu fark biyoklimatik konforu yükselterek kullanıcıların ortamdaki sıcaklıktan rahatsız olmamalarını sağlar. Bu da ortamın 1sıtılması ya da soğutulması için çok az enerjiye ihtiyaç duyulması demektir. Bu sayede kent içerisinde bitki kullanımı ile enerji etkinliği gerçekleşir. (Alpay ve ark., 2013).
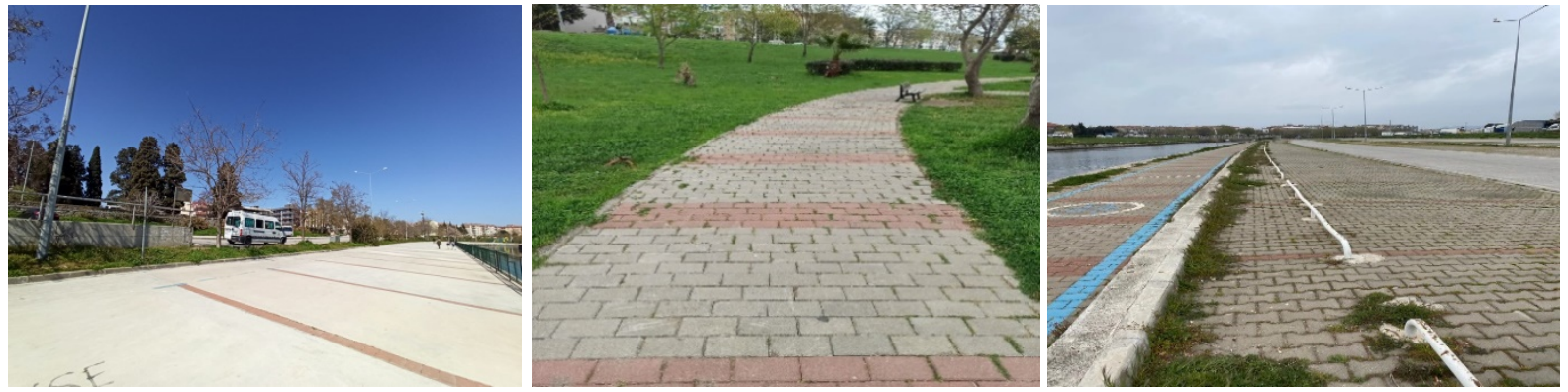

Şekil 3. Mevcut Sert Zeminler (Orijinal, 2021).

\subsubsection{Bitkisel öğeler}

Beckett ve ark. (1998), Yılmaz ve Irmak, (2004), Altay, (2012), Akça ve Gülgün Aslan, (2019)'a göre şehirlerde bulunan bitkilerin kullanıcılar üzerinde ruhsal ve bedensel etkileri öncelikli olmakla birlikte açık havada dolaşım imkânı tanıyarak kullanıcılara sağlıklı ve yararlı ortam oluşturma, flora ve faunaya yaşam ortamı sunma, 1şık yansımalarına engel olma, sıcaklık farkının ortadan kaldırılması, gürültü önleme, rüzgar, toz ve sera etkilerini en aza indirme, nem sağlama, hava kirliliğini azaltma gibi şehirlerin ekosistemine oldukça fazla yarar sağladığı saptanmıştır (Yazıcı ve Ünsal, 2019). Alanda sert zeminlere bağlı olarak geniş çim alanlar, yer yer küçük peyzaj parterleri, sıralı ağaç ve ağaçcık grupları ve çalılar bulunmaktadır. Sarıçay ve yakın çevresi üzerinde yer alan bitkiler alanda fazlasıyla kullanılan sert zeminlerin yarattığı 1Sı adası oluşumunun azalmasında rol oynamaktadır. Geniş yapraklı ağaçların yeterince kullanılmaması, alanda gölge mekânlar yaratmak açısından yetersiz kalmaktadır. Ayrıca alana doğallık katan bitkiler, kentliler için kentten uzaklaşarak rekreasyonel faaliyetlerini geçekleştirebilecekleri bir mekân yaratmakta ve kentin hava kalitesine katkı sağlamaktadır. Alanda geneli itibariyle kent iklimine uygun bitki türleri bulunmaktadır. Bitkiler alana görsel açıdan estetik değer katmaktadır. Alanda yer alan başlıca bitkiler; Cercis siliquastrum L. (Erguvan), Prunus cerasifera (Süs Eriği), Nerium oleander (Zakkum), Juniperus horizontalis(Yayılıcı Ardıç), Robinia pseudoacacia (Yalancı Akasya), Washingtonia filifera (Palmiye), Platanus orientalis (Çınar), Buxus sempervirens (Şimşir), Ligustrum lucidum (Kurtbağrı), Morus alba 'Pendula' (Sarkık dut), Elaeagnus angustifolia (Kuş iğdesi), Acer platanoides (Çınar yapraklı akçaağaç), Yucca filamentosa (Avize çiçeği), Paulownia tomentosa (Pavlonya)'dır (Şekil 4).
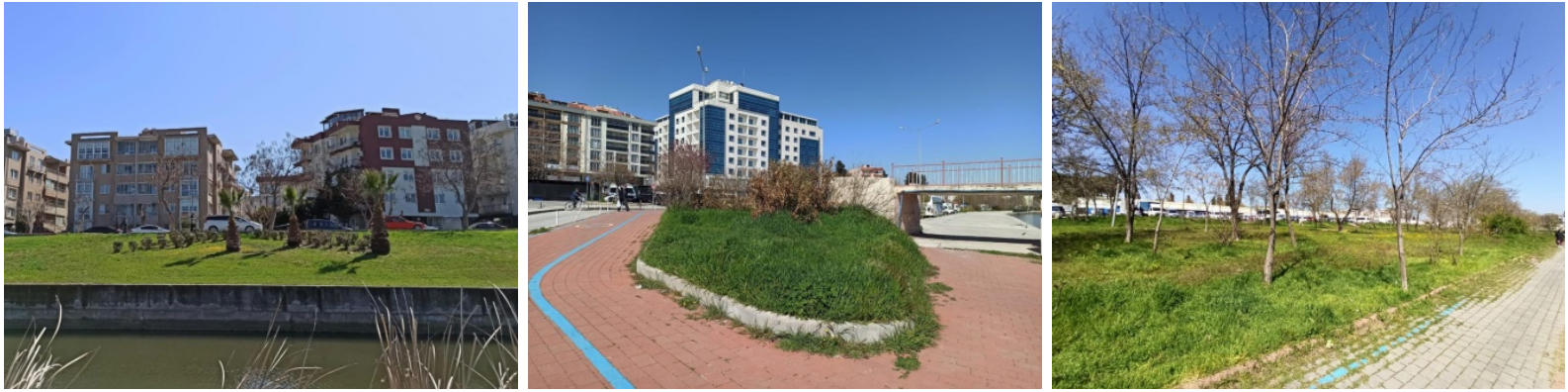

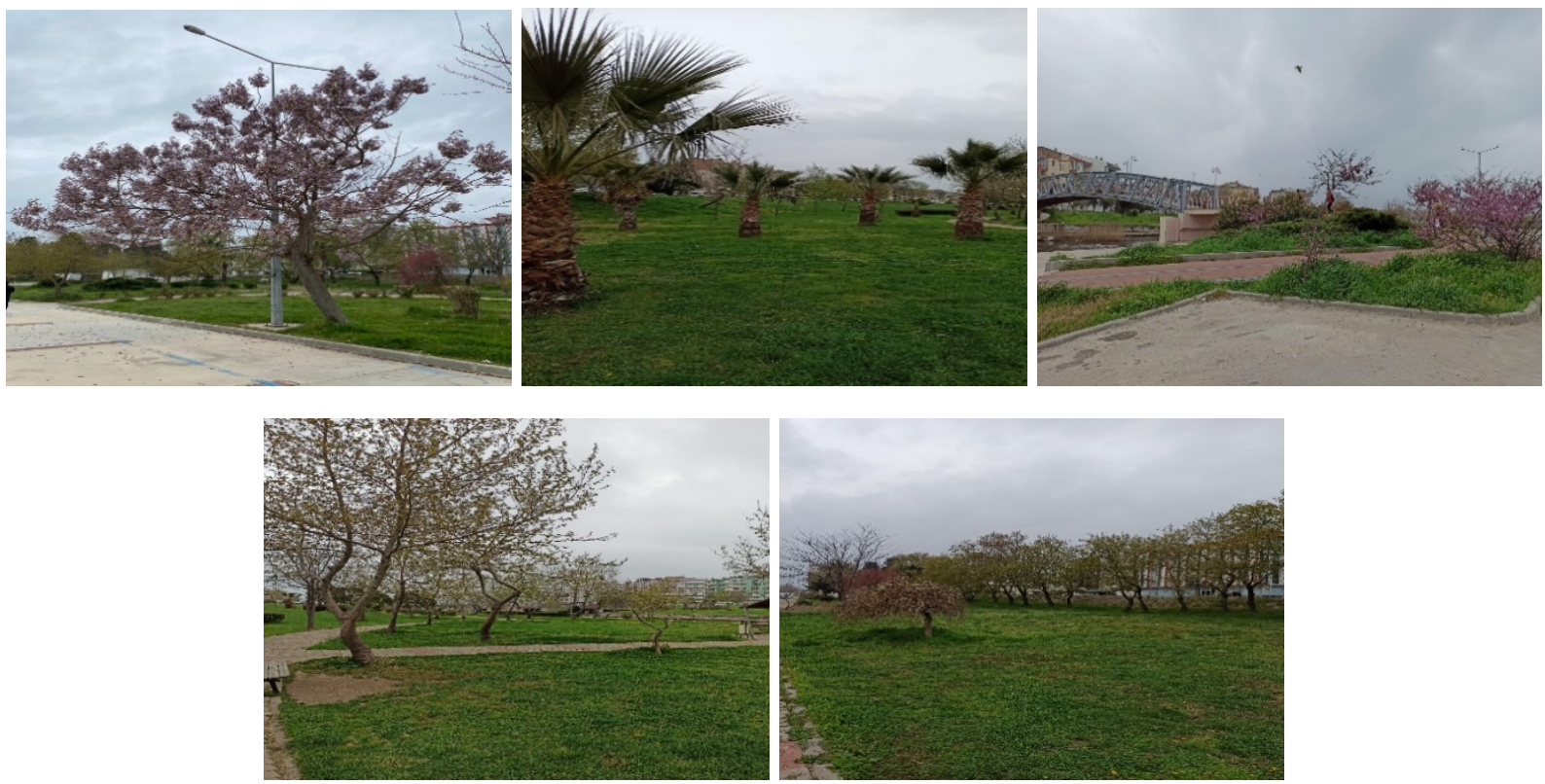

Şekil 4. Bitkisel Öğeler (Orijinal, 2021).

\subsection{4. Çöp Kutuları}

Çöp kutuları açık alanlarda kirlenmenin önüne geçerek çevrenin daha temiz kalmasını sağlayan, farklı yapı malzemeleriyle farklı modellerde meydana getirilen kent mobilyalarıdır. Alanda kullanılan diğer kent aksesuarları da göz önünde bulundurularak çöp kutularının konumlandırılması gerekmektedir (Şişman ve Yetim, 2004). Alan genelinde katı atıkların toplanması amacıyla renkli metal malzeme olarak bahçe çöp kutuları kullanılmışıtır. Yer yer soyulma ve paslanmalar görülen çöp kutuları alanda görüntü kirliliğine neden olmaktadır. Alanda ayrıca çöp kutularına nazaran daha az sayıda bulunan çöp konteynerleri de yer almaktadır. Ayrıca Sarıçay Nehri ve yakın çevresinde kullanılan çöp kutuları, yayaların geçişini engellemeyecek şekilde alan içerisinde konumlandırılmıştır (Şekil 5).
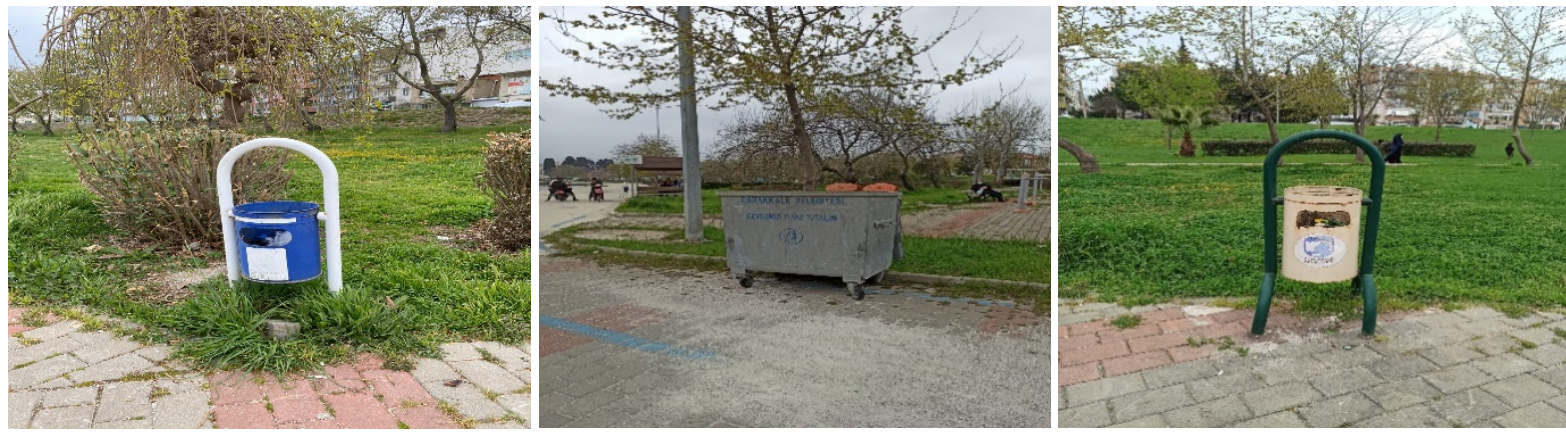

Şekil 5. Katı Atık Çöp Kutuları (Orijinal, 2021).

\subsubsection{Alan Kullanımları}

Çalışma alanında kullanıcılara yönelik bisiklet ve yürüyüş yolu, oturma-dinlenme elemanları, çocuk oyun parkları, spor aletleri, alan içinde geçiş köprüleri, Çanakkale Pazarı ve basket sahası bulunmaktadır. Bu alan kullanımları, kullanıcıların hafta içi ve hafta sonları rekreasyonel ihtiyaçlarını karşılamaktadır (Şekil 6). Peyzaj Mimarlığı tasarım ilkeleri doğrultusunda incelendiğinde ise; alanda denge, uyum ve birlik söz konusu değildir. Alan kullanımları Sarıçay boyunca zemine yayılmamış, sadece belli bir alanda toplanmıştır. Çim alanların farklı şekil ve formlarda tekrar etmesi, alanda devamlılık sağlamıştır. Alanda, vurgulayıcı herhangi bir görsel unsur kullanılmamıştır. Bu da alanın tekdüze 
görüntü vermesine neden olmuştur. Tüm bunlar göz önünde bulundurulduğunda alanın sahip olduğu en büyük odak noktası olan su öğesi bile alanı dikkat çekici kılmaya yeterli olamamışır.
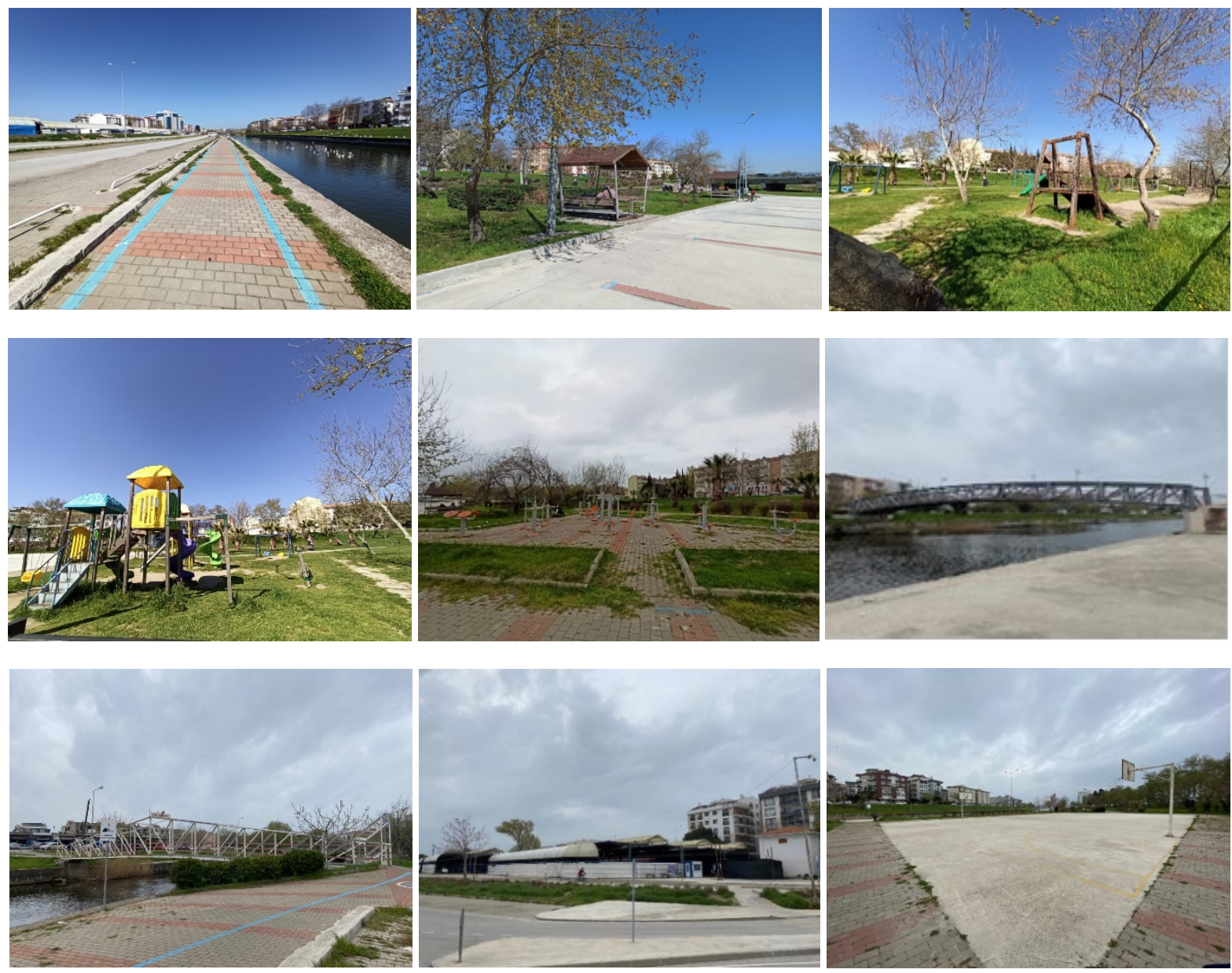

Şekil 6. Alan Kullanımları (Orijinal, 2021).

\section{Değerlendirme ve Öneriler}

Sarıçay Nehri ve yakın çevresi ekolojik peyzaj tasarımı yönünden yeterli olmadığı, alandan maksimum verim alınamadığı, Sarıçay Nehri ve yakın çevresinin detaylı bakım ve onarıma ihtiyaç duyduğu tespit edilmiştir. Peyzaj tasarım ve yönetimi ekolojik yaklaşımları doğrultusunda; çalışma alanında sürdürülebilirliğini sağlayarak yeşil kuşaklar oluşturmak adına gerekli olan ekolojik yaklaşım önerileri aşağıda verilmiştir. Çalışma için Sarıçay Nehri ve yakın çevresi ile benzerlik gösteren Fransa'nın Paris şehrinde bulunan Seine Nehri örnek olarak alınmış, karşılaştırmalı olarak tasarım önerileri getirilmiştir.

Alanda bulunan yaklaşık 1.07 km'lik Sarıçay Nehri ve yakın çevresi bakımsız ve kirli görüntüsüyle dikkat çekmektedir. Kirli suyun yarattığı hava, görüntü ve koku kirliliğinin ortadan kaldırılması, suyun arındırılması ayrıca endüstriyel ve evsel atıkların Sarıçay Nehrine yönlendirilmesinin önüne geçilmesi sağlanmalıdır. Paris'te şehri ikiye bölen Seine Nehri'nin sahip olduğu su öğesi ise oldukça temiz ve bakımlıdır. Görüntü olarak bu temizlik baz alınarak Sarıçay Nehrinin yenilenmesi geçekleştirilmelidir (Şekil 7). 

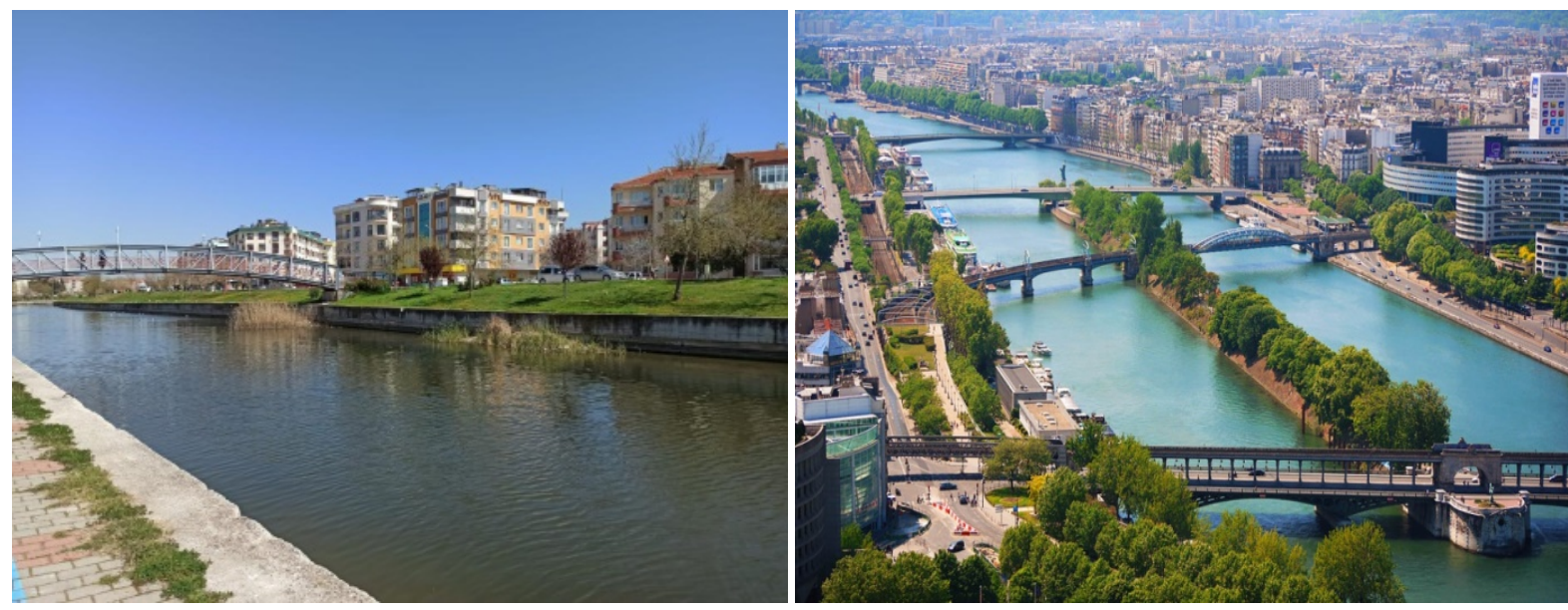

Şekil 7. Sulak Alanlar (Orijinal, 2021 ve URL-2'den değiştirilerek)

Alanda sert zeminler oldukça işlevsiz ve sadece 1sı adası yaratacak şekilde yoğun olarak kullanılmışıtır. Kullanım alanlarının ve yeşil alanların azlı̆̆ Sarıçay Nehri ve yakın çevresinin çıplak görünmesine neden olmuştur. Bu boş görüntüyü ortadan kaldırmak ve alanın daha etkin kullanılmasını sağlamak amacıyla çeşitli kullanım ve aktivite alanları oluşturulmalı, kullanıcılar için konfor unsuru geliştirilmelidir. Seine Nehrine bağlı sert zeminler ise çeşitli kullanımlarla zenginleştirilerek yeşil dokuyla bütünleştirilmiş kullanıcıların zaman geçirmekten zevk aldığı memnuniyet ve kullanım oranı yüksek mekânlar ortaya çıkmıştır (Şekil 8).
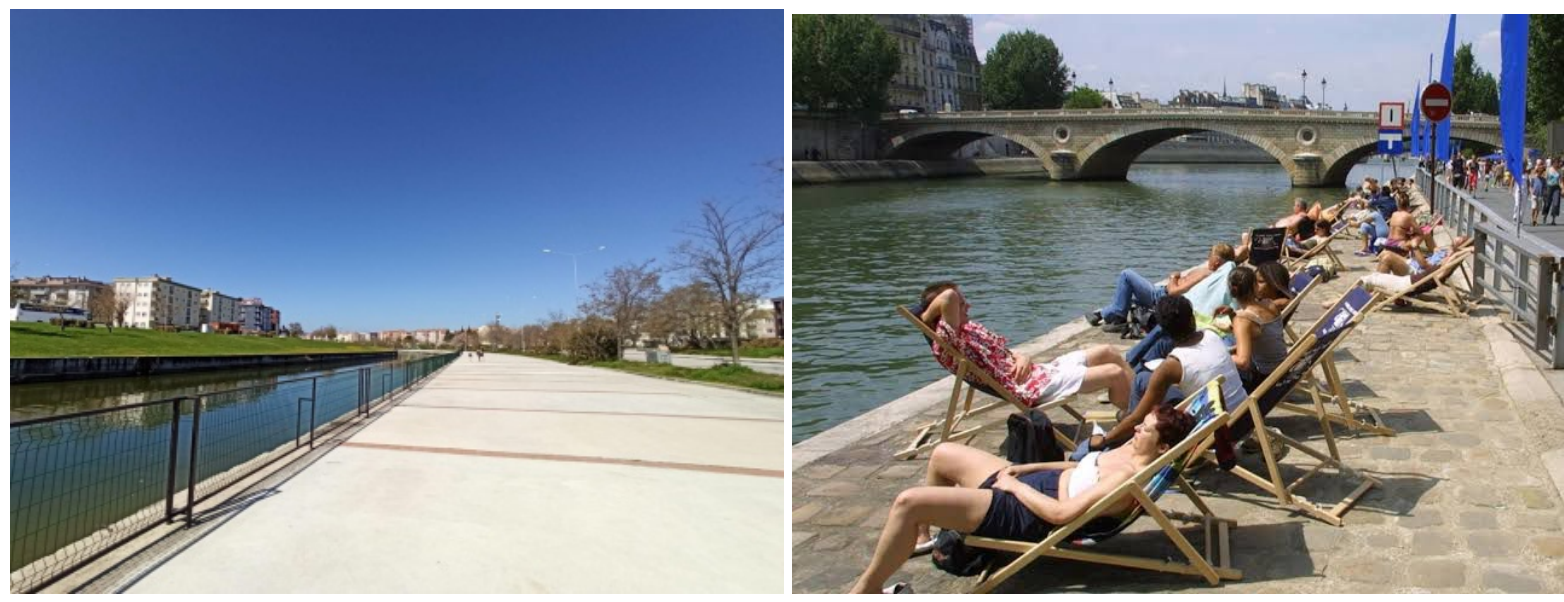

Şekil 8. Sert Zeminler (Orijinal, 2021 ve URL-3'ten değiştirilerek)

Alanda yeşil alanlar sürekli olarak sert zeminlerle kesintiye uğramış, sağlıklı bir yeşil sirkülasyon sağlanamamıştır. Yeşil zeminlere oranla alan genelinde sert zeminler yoğunluktadır. Aynı zamanda az ağaç kullanımının neden olduğu çıplak görünüm hâkimdir. Alanda yeşil alanların sürekliliğinin sağlanması amacıyla, sert zeminlerin azaltılması ya da mevcut sert zeminlerin yeşil dokuyla kaplanması gerekmektedir. Olası boş görüntü ise boylu, yapraklı ağaç ve ağaçıkların kullanımı ile ortadan kaldırılmalıdır. Ayrıca alanda her mevsim farklı renk etkisi oluşturacak bitkiler tercih edilerek, alanın görsel çekiciliği artırılmalıdır. Sarıçay Nehri ve yakın çevresinde, ekolojik bakımdan sürdürülebilirliğin devam edebilmesi ve habitat bölünmesinin önüne geçilerek biyolojik çeşitliliğin sağlanması adına alan üzerinde yeşil kuşak oluşturulmalıdır. Seine Nehri yakın çevresinde ise doğrusal olarak oluşturulan sıralı ağaç grupları alanda yeşil kuşakların oluşturulmasını sağlamıştır. Bu oluşum alanın görüntü kalitesini artırarak, şehir merkezinde doğa ile iç içe bir mekân oluşturmuştur. Bu mekân oluşturulurken çeşitli renklerde bitkilerden yararlanmak yerine tekdüzelik ve sadelik ön plana çıkarılmıştır, alanı renklendirmek amacıyla sonbahar renklenmesi tercih edilmiştir (Şekil 9). 

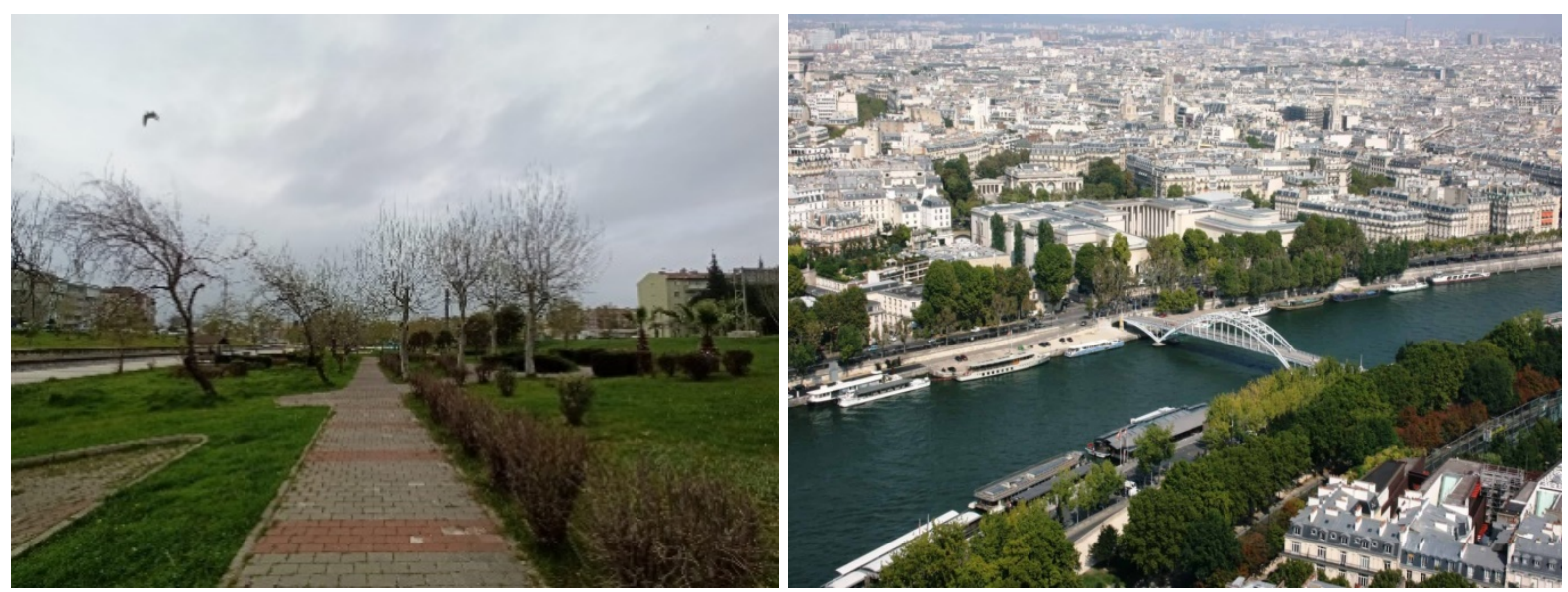

Şekil 9. Bitkisel Öğeler (Orijinal, 2021 ve URL-4'den değiştirilerek)

Alanda kullanılan, yer yer soyulma ve paslanma görülen çöp kutularının bakım ve onarımının düzenli olarak yapılması sağlanmalıdır. Alanla uyumlu olması açısından büyük çöp konteynerleri yerine ahşap, taş ya da alanın renk kombinasyonuna uygun çöp kutuları tercih edilmelidir. Seine Nehri yakın çevresinde ise ağırlıklı olarak plastik poşetli çember çöp kutuları kullanılmıştır. Bu kullanım donatı elemanında oluşacak çeşitli bakım ve onarım sorunlarının önüne geçmektedir; fakat aynı zamanda çöp içeriğini göz önüne sererek görüntü kirliliği oluşturmaktadır (Şekil 10).
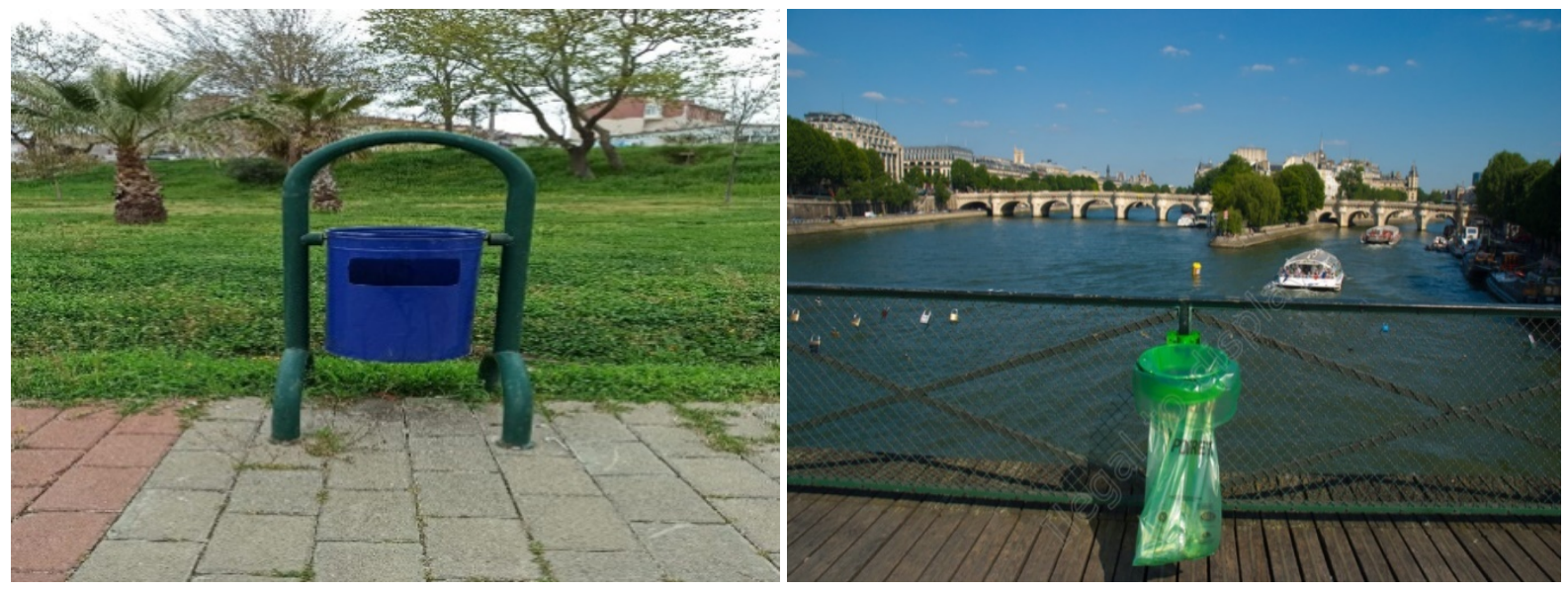

Şekil 10. Çöp Kutusu (Orijinal, 2021 ve URL-5'den değiştirilerek)

Sarıçay Nehri ve yakın çevresinde mevcut olarak bulunan alan kullanımları, kullanıcılar için mekânın daha aktif kullanılmasına olanak sağlaması açısından yeterli değildir. Özellikle oturma elamanları, alanın yalnızca belli bir noktasında kullanılmış alan genelinde yayılmamışıtır; bu da kullanımlara erişim sıkıntısına neden olmaktadır. Dolayısıyla alan kullanımları Sarıçay Nehri ve yakın çevresine yayılmalı ve bölgesel kullanımdan uzaklaştırılmalıdır. Alanda, alanı daha dikkat çekici bir mekân haline getirmek amacıyla; pasif oyun alanları (langırt, masa tenis vb.), yoga alanı, müzikli eğlence alanları gibi farklı kullanımlar seçilmelidir. Seine Nehri yakın çevresinde kullanıcıların daha çok dinlenmesi ve oturması amacına yönelik alan kullanımları tercih edilmiştir. Nehir boyunca uzanan ahşap oturma alanları, güneşlenme ve yapay plaj alanı, hizmet veren kafeler yer almaktadır (Şekil 11). 

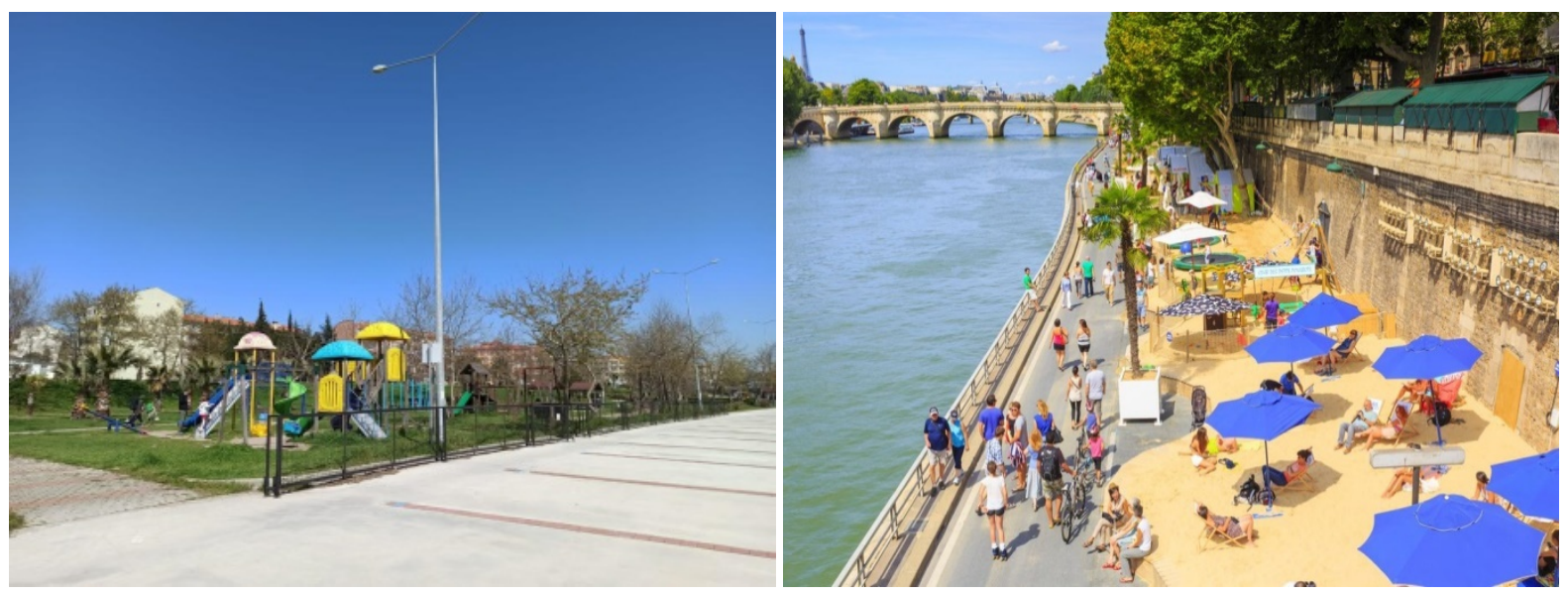

Şekil 11. Alan Kullanımı (Orijinal, 2021 ve URL-6'dan değiştirilerek)

\section{SONUÇ:}

Sonuç olarak; çalışma alanı, ekolojik peyzaj tasarımı kriterleri doğrultusunda incelendiğinde bu kriterleri karşılamadığı tespit edilmiştir. Bu durumun başlıca sebepleri şu şekilde sıralanmıştır;

- Sulak alanların bakımsız ve kirli olması ve buna bağlı olarak görüntü kirliliği oluşturması,

- Sert zeminlerin alana oldukça hâkim olarak 1sı adaları yaratması, alanı doğallıktan uzaklaştırması,

- Alanda bitkisel tasarımların oldukça yetersiz ve kopuk olması,

- Çöp kutularının düzenli bakımının gerçekleştirilmemesi ve buna bağlı ortaya çıkan koku kirliği, Kullanılan yapı malzemelerinin alanla entegre edilmemesi

- Alan kullanımlarının Sarıçay Nehri ve yakın çevresi boyunca genele yayılması yerine tek bir noktada toplanması buna bağlı olarak alanda oluşan boş görüntü,

- Alanda çeşitli aktivitelerin bulunmamasına bağlı olarak yeterince kullanıcıya hitap etmemesi ve bu nedenle alanda oluşan tehlikeli ve güvensiz algı şeklindedir.

Tüm bu sebepler göz önünde bulundurulduğunda, alanda sürdürülebilirliğin sağlanabilmesi ve alanın halka ve şehre kazandırılabilmesi amacıyla ekolojik tasarım önerileri doğrultusunda alanda değişiklikler yapılması gerekmektedir. Alana yönelik geliştirilen tasarım önerileri başlıca şu şekildedir;

- Nehir yüzey ve dibinde bulunan, katı atıkların ve çürümüş bitkilerin sudan temizlenmesi sağlanmalıdır. Özellikle evsel ve endüstriyel atıkların nehre dökülmesinin engellenmesi, suyun da devir daim özelliğiyle zamanla kendi kendini yenilemesini sağlayacaktır.

- Sert zeminler alanda güneş 1şığııı soğurmadan ışığın emilimine neden olarak ortamın sıcaklığını oldukça arttırmaktadır. Bu zeminlerin yoğun olarak kullanılması sonucu meydana gelen 1S1 adası etkisi sorununun önüne geçmek amacıyla sert zeminler azaltılarak bitkisel dokunun arttırılması gerekmektedir.

- Alan üzerinde biyolojik çeşitliliğin ve doğanın devamlılı̆̆ının sağlanması adına nehir boyunca yeşil kuşak oluşturmalıdır. $\mathrm{Bu}$ sayede kentlilerin kent ortamından uzaklaşarak doğaya yaklaşması ve alanın sürdürülebilirliğinin sağlanması gerçekleşecektir. Alanın açık bir mekân olması sebebiyle güneşlenme alma oranı oldukça fazladır. Bu nedenle alanda gölge sağlamak amacıyla boylu ve geniş yapraklı ağaçlar tercih edilmelidir. Kış kullanımıyla birlikte alanda oluşturulacak kaligrafik görüntü için yaprak döken ağaçların 
kullanılması gerekmektedir. Alanda mevsimsel renk etkisi sağlayacak ağaç ve çalıların kullanılması ise görsel çekiciliği arttıracaktır.

- Alan üzerinde bulunan çöp kutularının düzenli bakım işleri gerçekleştirilmeli, olası koku kirliliğinin önüne geçilmelidir. Alanı doğala yakınlaştırmak amacıyla kullanılan yapı malzemesinin ahşap olması, görüntü kalitesini arttırarak doğa ile uyumunu sağlayacaktır.

- Alan kullanımları Sarıçay Nehri ve yakın çevresi boyunca yayılmalı alanın genelinin aktif bir şekilde kullanıcılar tarafından kullanılması sağlanmalıdır. Aktivite çeşitliliğinin arttırılması (çeşitli spor kortları, pasif oyun alanları, güneşlenme alanları vs.) ve alanın her köşesinin doğru bir şekilde aydınlatılarak gece kullanımının da sağlanması gerçekleştirilerek alanın güvensiz ve tehlikeli algısı kırılmalıdır.

\section{Etik Standart ile Uyumluluk}

Çıkar Çatışması: Yazarlar herhangi bir çıkar çatışmasının olmadığını beyan eder.

Etik Kurul İzni: Bu çalışma için etik kurul iznine gerek yoktur.

Finansal Destek: Yoktur.

\section{Teşekkür:}

\section{KAYNAKÇA:}

Akça, Ş. B. ve Aslan, B. G. (2019). Kampüs Yaşamında Estetik ve Fonksiyonel Açıdan Süs Bitkilerinin Yeri ve Önemi; Çaycuma Kampüsü Örneği. Bartın Orman Fakültesi Dergisi, 21(2), 267-279.

Aklanoğlu, F. (2009). Geleneksel Yerleşmelerin Sürdürülebilirliği ve Ekolojik Tasarım: Konya-Sille Örneği. Ankara Üniversitesi, Fen Bilimleri Enstitüsü (Doktora Tezi). Ankara.

Aklanoğlu, F. ve Erdoğan, E. (2011). Sille (Konya) Yerleşiminin Sürdürülebilirliği için Ekolojik Tasarım Önerileri. Tekirdağ Ziraat Fakültesi Dergisi, 8(2), 119-131.

Alpay, C. O., Kalaycı, A. ve Biriş̧̧i, T. (2013). Ekolojik Tasarım Kriterlerine Göre Kent Parkı İyileştirme Modeli: İzmir Kültürpark Örneği. TMMOB İzmir, 2, 328-343.

Altay, V. (2012). The Ornamental Plants of Tayfur Ata Sökmen Campus of Mustafa Kemal University. The Black Sea Journal of Science, 2(6), 11-26.

Aşur, F. (2017). Van Kenti Yakın Çevresi Kıyı Alanı Örneğinde Sulak Alanlar ve Görsel Peyzaj Kalite Değerlendirmesi. Türk Tarım ve Doğa Bilimleri Dergisi, 4(4), 506-515.

Atıl, A., Gülgün, B. ve Yörük, İ. (2005). Sürdürülebilir Kentler ve Peyzaj Mimarlığı. Ege Üniversitesi Ziraat Fakültesi Dergisi, 42(2), 215-226.

Beckett, K. P., Freer-Smith, P. H. \& Taylor, G. (1998). Urban woodlands: their role in reducing the effects of particulate pollution. Environmental pollution, 99(3), 347-360.

Çelikyay, S. ve Karayılmazlar, A. S. (2016). Bartın Kent Merkezindeki Kamusal Alanların Kentsel Ergonomi ve Kent Kimliği Açısından İncelenmesi. Bartın Orman Fakültesi Dergisi, 18(2), 224-238.

Deng W., Browell M. \& Wareham, Z. (2008). Applying Ecological Landscape Design Principles to University Planning. Journal of Green Building, 3(4), 95-107. 
Emery, M. (1986). Promoting Nature in Cities and Towns : A Practical Guide. Croom Helm. London.

Erdoğan, E. ve Aklanoğlu, F. (2011). Sille (Konya) Yerleşiminin Sürdürülebilirliği için Ekolojik Tasarım Önerileri. Tekirdă̆ Ziraat Fakültesi Dergisi, 8(2), 119-131.

Eugenio A. ve Ortiz L. (2003). Questioning Ecological Design: A Deep Ecology Perspective. Ecotecture-The Online Journal of Ecological design.

Girginer, D. (2006). Kentsel Tasarım ile Ekolojik Sürdürülebilirliğin İlişkilendirilmesi ve Toplu Konut Gelişme Bölgelerinde Örneklenmesi. Dokuz Eylül Üniversitesi, Fen Bilimleri Enstitüsü, (Yüksek Lisans Tezi). İzmir.

Gökşen, F., Güner, C. ve Koçhan, A. (2017). Sürdürülebilir Kalkınma İçin Ekolojik Yapı Tasarım Kriterleri. Akademia Disiplinlerarası Bilimsel Araştırmalar Dergisi, 3(1), 92-107.

Korkut, A., Kiper, T. ve Topal, T. Ü. (2017). Kentsel Peyzaj Tasarımda Ekolojik Yaklaşımlar. Artium, 5(1), 14-26.

Moore C.W. \& Lidz J, (1994). Water and Architecture, Thames and Hudson, Hardcover CT, U.S.A. 224.

Onur, B. E. (2012). Peyzaj Tasarım ve Yönetiminde Ekolojik Yaklaşım ve Sürdürülebilir Kent Hedefine Katkıları. İönü Üniversitesi Sanat ve Tasarım Dergisi, 2(5).

Sağlık, A. (2010). Çanakkale Kent Kıyısının Kentsel Peyzaj Tasarımı Açısından İncelenmesi. Çanakkale Onsekiz Mart Üniversitesi, Fen Bilimleri Enstitüsü (Yüksek Lisans Tezi). Çanakkale.

Sağlık, A., Erduran, F. ve Çelik, A. (2012). Kent İçi Akarsuların Rekreasyonel Yönden Kullanımı: Çanakkale Sarıçay Örneği. Research Journal of Biology Sciences, 5(1), 43-48.

Sağlık, A., Kelkit, A. ve Sağlık, E. (2012). Kentsel Kıyı Alanlarında Yerleşim Baskısı Sonucu Oluşan Çevresel Sorunlar: Çanakkale Kenti Örneği. Research Journal of Biology Sciences, 5(2), 145-149

Sağlık, A., Sağlık, E. ve Kelkit, A. (2014). Kentsel Donatı Elemanlarının Peyzaj Mimarlığı Açısından İrdelenmesi: Çanakkale Kent Merkezi Örneği. 1. Uluslararası Kentsel Planlama-Mimarlık-Tasarım Kongresi, Kocaeli, Türkiye, 811.

Sev, A. (2009). Sürdürülebilir Mimarlık, 1. Baskı, Yem Yayınları, İstanbul, 223s.

Tunçer, S. (2021). Çanakkale Sarıçay'da Su Samurunun Yaşama Ortamları. Erişim adresi: http://www.akyaka.org/otter/bilgi_tr/beymelek_2002/habitat $\% 20 \% 20$ of $\% 20 \% 20$ otter $\% 20 \% 20 \mathrm{in} \% 20 \% 20$ canakkale $\%$ $\underline{20 \% 20 \text { saricay } \% 20 \% 20 \text { stream.pdf }}$

Tülek, B. (2010). Bayındır Barajı Örneğinde Kentsel Alanlar ve Yakın Çevresinde Yer Alan Su Kıyılarının Ekolojik Planlama ve Tasarım İlkeleri. Ankara Üniversitesi, Fen Bilimleri Enstitüsü (Yüksek Lisans Tezi). Ankara.

Yazıcı, K. ve Ünsal, T. (2019). Kentsel Yaşam Kalitesi Açısından Süs Bitkilerinin Önemi; Tokat/Merkez-Yeşilırmak Örneği. Ziraat Mühendisliği, (367), 66-76.

Yeang, K. (2008). Ken Yeang'ın Ekolojik Tasarım Yaklaşımı. Yapı Dergisi, Sayı: 318 (Mayıs), S. 112-118, İstanbul.

Yılmaz, H. ve Irmak, M. A. (2004). Erzurum Kenti Açık-Yeşil Alanlarında Kullanılan Bitki Materyalinin Değerlendirilmesi. Ekoloji, 13(52), 9-16.

URL-1

https://www.haritatr.com/harita/saricay/107098\#: :text=Sar\%C4\%B1\%C3\%A7ay\%20Marmara\%20b\%C3\%B6lgesin de\%20yer\%20almakta,26.3992\%20boylam\%20olarak\%20haritada\%20g\%C3\%B6sterilmektedir, (Erişim Tarihi: $08.05 .2021)$

URL-2 https://www.interbustur.com/sen-nehri/, (Erişim Tarihi: 08.05.2021) 
URL-3 https://www.nytimes.com/2018/09/06/travel/what-to-do-in-paris-on-the-seine.html, $\quad$ (Erişim Tarihi: 08.05.2021)

URL-4 https://pxhere.com/en/photo/1090149, (Erişim Tarihi: 08.05.2021)

URL-5 https://www.peterforsbergphotography.com/p/24242hnx/4247918650/bin-can-garbage-litter-rubbishcontainer, (Erişim Tarihi: 08.05.2021)

URL-6 https://www.smithsonianmag.com/travel/paris-river-has-become-beach-180952270/, (Erişim Tarihi: 08.05.2021) 